\title{
Sugarcane companies' preferences for certified suppliers in the supply chain
}

\author{
Eduardo José Oenning-Soares ${ }^{1}$ (i), Lucas Ambrosio Bezerra de Oliveira ${ }^{2}$ (i), \\ Fagner José Coutinho de Melo ${ }^{3}$ (D), Larissa de Arruda Xavier ${ }^{4}$ (1) , Denise Dumke de Medeiros ${ }^{4}$
}

${ }^{1}$ Mato Grosso State University - UNEMAT, Production Engineering Department, Barra do Bugres, MT, Brazil.

${ }^{2}$ Federal University of the Semi-Arid Region - UFERSA, Engineering Department, Multidisciplinary Center of Angicos, Angicos, RN, Brazil.

${ }^{3}$ University of Pernambuco - UPE, Business Department, Recife, PE, Brazil.

${ }^{4}$ Federal University of Pernambuco - UFPE, Production Engineering Department, Recife, PE, Brazil.

How to cite: Oenning-Soares, E.J., Oliveira, L.A.B., Melo, F.J.C. et al. (2020), “Sugarcane companies' preferences for certified suppliers in the supply chain", Brazilian Journal of Operations \& Production Management, Vol. 17, No. 4, e2020965. https://doi.org/10.14488/BJOPM.2020.047

\section{ABSTRACT}

Goal: The main objective of this study was to evaluate the preference structure for MSS certifications in a Brazilian supply chain.

Design / Methodology / Approach: To form the set of attributes, five MSS were selected that certify companies in the Brazilian sugarcane supply chain, and a sample of 66 large and medium-sized companies in operation was obtained.

Results: The results show that the Brazilian sugarcane companies supply chain presented a higher preference for suppliers with ISO 9001 (38.7\%), ISO 22000 (19.9\%), ISO 14001 (19.6\%), OHSAS 18001 (13.2\%) and ISO 27001 (8.6\%) certification and contribute to the literature by offering new and broader insight into industrial buying behavior in the business-to-business context with respect to the adoption of MSS.

Limitations of the investigation: The low number of observations may be a factor limiting the investigation. And the study is limited to sugar-alcohol companies in Brazil.

Practical implications: Companies within the supply chain still prefer the traditional certifications, even when the market is saturated with such certifications. These results help better explain industrial behavior and illuminate the relationships that companies develop within the supply chain, that might thus be of great assistance to suppliers wishing to become part of this supply chain by identifying which MSS certifications are most valued by purchasing companies.

Originality / Value: The article analyzes which MSS are most important for the Brazilian companies of sugar cane and ethanol. And can be of great value to managers, suppliers, and stakeholders in this industry, as well as a model for developing countries.

Keywords: Conjoint Analysis; Supply Chain; Management System Standards; Sugarcane Companies; Agribusiness.

\section{INTRODUCTION}

Organizations seek certification for various activities and processes with management system standards (MSS) such as those proposed by the International Organization for Standardization (ISO) and Occupational Health and Safety Assessment Services (OHSAS) (Liu et al., 2020). As a result, the number of international MSS has grown rapidly over the last decades since the introduction of the ISO 9001 Quality standard in 1987 (Bornia et al., 2016).

Financial support: The authors are grateful for the support received to conduct this study from the Conselho Nacional de Desenvolvimento Científico e Tecnológico (CNPq), the Fundação de Amparo à Pesquisa do Estado de Mato Grosso (FAPEMAT), the Fundação de Amparo à Ciência e Tecnologia do Estado de Pernambuco (FACEPE), the Coordenação de Aperfeiçoamento de Pessoal de Nível Superior (CAPES) Financing Code 001, the Brazilian governmental entities that promote scientific and technological development.

Conflict of interest: The authors declare that they have no conflict of interest associated with this research.

Corresponding author: eduardo.oenning@unemat.br

Received: 11 May 2020.

Approved: 7 Oct 2020

Editor: Osvaldo L. G. Quelhas.

cC (i) This is an Open Access article distributed under the terms of the Creative Commons Attribution License, which permits unrestricted use, c) distribution, and reproduction in any medium, provided the original work is properly cited. 
Examining the peculiarities of each market segment, such as in supply chains, it is possible to perceive the implications of these certifications when business and transactions occur between companies (Khan and Farooquie, 2016; Lizarraga et al., 2020; Su et al., 2020).

Some of these implications are linked with the dynamics and globalization of such markets, with the result that relations between companies increasingly involve aspects such as trust, credibility, cooperation (Polo-Redondo and Cambra-Fierro, 2008; Sharma et al., 2015) and substantial pressure from customers and society concerning standardized processes and products.

These certifications are important in the agribusiness context because they help achieve the above-referenced objectives and thus can help improve long-term relationships and strengthen the supply chains within which firms operate (Polo-Redondo and Cambra-Fierro, 2008). In addition, operations such as asset management, shared services, fleet management, and outsourcing may be improved, since there are several operations in which organizations (clients and suppliers) seek partners who take responsibility for them (Fava Neves et al., 2010).

Moreover, regarding to the reasons for certification, as observed in del Mar AlonsoAlmeida et al. (2013), another reason for implementation of certifications is that MSS-certified companies generally prefer to utilize other certified suppliers (Ferguson, 1996; Cashore, 2002; Christmann and Taylor, 2002; Stevenson and Barnes, 2002; Fraj et al., 2013; Ramos et al., 2018; Su et al., 2020), resulting in certification pressure up and down the supply chain (Miles et al., 1997; Karapetrovic and Willborn, 1998a; 1998b; Karapetrovic, 2003; Nishitani, 2009, 2010; Su et al., 2020).

Miles et al. (1997) noted that the standards movement typically cascades through the supply chain and that this phenomenon has been an important driver of ISO 9001 certification in recent decades (Boiral, 2003; Prajogo, 2011; Su et al., 2020). Christmann and Taylor (2006) note that suppliers are more likely to choose certification when clients consider MSS important, leading suppliers to seek certification to secure clients and strengthen their role within the supply chain. This type of scenario may also result in increased interest in and preference for certified suppliers (Su et al., 2020).

In other fields, researchers have stressed that certification is less attractive to companies when the number of certified companies reaches a certain limit because certification begins to lose its ability to differentiate (Franceschini et al., 2004, 2006; Casadesús et al., 2008), thus influencing the preference for certifications and certified suppliers (Desai, 2018).

Thus, when firms located further up the supply chain lose their preference for MSScertified suppliers, firms throughout the supply chain will tend to follow suit, and both industrial buying behavior and the relationships that companies develop within the supply chain are likely to reflect the same diminished preference (Gray et al., 2015).

Based on this concise review, the following research problems are derived: (1) What is the preference order, among the MSS analyzed in this study, noted by the agro-sugar companies? (2) What is the degree to which firms prefer MSS? (3) When the number of certified companies reaches a certain limit such that a standard becomes common, will the preference for certified suppliers be influenced in either an upward or a downward direction?

In view of the foregoing, this paper's goal is to verify the existence and dynamics of contracting sugarcane companies' preference for companies that provide certified services with prominent ISO 9001, ISO 14001, ISO 22000, ISO 27001 and OHSAS 18001 certifications. To do so, a multivariate statistical technique called "conjoint analysis" was used because it allows verification of this preference.

This manuscript is justified by the perceived importance of certification and the relevance of the theme in relation to the analysis of customer preferences by certified companies in supply chains (Rosa et al., 2019). In addition, the possible weakening of customer preferences by a specific certification can affect the perceived importance of the document by a supplier, which may influence the relationships that such companies develop in the supply chain (Corbett and Kirsch, 2001), factors that reinforce the importance and need for research in this area. For this purpose, an empirical study was conducted, employing data from Brazilian companies in the sugarcane sector to analyze manufacturer preferences regarding certified 
suppliers, where the Brazilian sugarcane sector has gained international prominence based on the production of ethanol as an alternative for renewable fuel (Freitas and Kaneko, 2011).

In this way, the country has become a global standard for biofuel production technology with export potential, as it is the world's largest producer of sugarcane and one of the world's largest producers of ethanol (Hira and Oliveira, 2009).

Brazilian sugarcane and ethanol companies have sought MSS certification to become more attractive in international markets and to facilitate or even enable an export process, mainly with respect to the European Union and Asia. However, suppliers that wish to enter this supply chain may encounter difficulties in deciding which certification to adopt because they are unaware of their (potential) clients' preferences.

This sector is of great importance to the Brazilian economy because it is responsible for $40 \%$ of the world's sugarcane production, making Brazil the world's largest producer of sugar (Gilio and Moraes, 2016; Pagani et al., 2017).

Another factor in the choice of the sugarcane sector was the country's placement in ethanol production. Brazil ranks second in the production of this product, behind only the United States (Licht, 2007; Renewable Fuels Association, 2014). The sector studied has many attributes that make it a good example of sustainable agroindustry. Accordingly, this study's contributions can support analyses that involve the proposed objective in other regions and economies of the world, especially in developing countries.

\section{MSS CERTIFICATIONS IN B2B RELATIONSHIPS AND SUPPLIER PREFERENCES}

Over time, research on relationships between companies and service providers in the supply chain has evolved from investigations of business transactions between firms to include additional dimensions, such as social, emotional, reciprocity, mutual benefit, cooperation, and technological dimensions (Fraj et al., 2013; Kumar and Rahman, 2015). Additionally, as technology makes products more complex and customers demand progressively more customized offerings, organizations are increasingly required to address greater complexity in the supply chain, both in terms of the number of suppliers and in their varying characteristics, both of which affect the supply chain in many marketplaces (Vachon and Klassen, 2002; Ge et al., 2015), including agribusiness (Proches and Bodhanya, 2015; Behzadi et al., 2017).

Regarding the complexity presented in the supply chain, the standardizing and certifying certain production and management processes have had important effects on the relationships that those firms develop (Polo-Redondo and Cambra-Fierro, 2008).

The increase of MSS reflects the importance that companies attach to improving the internal efficiency of their management systems (del Mar Alonso-Almeida et al., 2013). In an economic environment in which outsourcing business activities has become a central strategic element in supply chains (Vafaei et al., 2019), a certain homogeneity in management systems must be promoted that may be achieved with the assistance of MSS (Heras-Saizarbitoria and Boiral, 2013) and may generate positive externalities for company competitiveness within the market. To operationalize this homogeneity, a wide range of MSS are available that cover almost all functional areas of the organization and that aim to improve client confidence for both internal and external customers (Sampaio et al., 2012; Özdemir et al., 2015).

The appearance and adoption of the MSS has had a strong influence on industrial buying behavior and, consequently, on the relationships that firms develop within the supply chain (Czinkota et al., 2014; Hoejmose et al., 2014). Polo-Redondo and Cambra-Fierro (2008) stressed that certified suppliers have a positive influence on the communication, commitment, satisfaction, and long-term orientation of their supply relationships.

Similarly, studies indicate that certifying production and management processes helps increase a company's credibility by increasing client confidence in suppliers (Chatterjee et al., 2005; Aldowaisan and Youssef, 2006), generating a significant reduction of uncertainty in supply management (Chatterjee et al., 2005) and enhancing reputation, which results in competitive benefits (Hoejmose et al., 2014). For these reasons, certified companies are more likely to select and establish relationships with certified suppliers (Cashore, 2002; Christmann and Taylor, 2002, 2006; Fraj et al., 2013). 
In Brazil, Almeida et al. (2009) found that ISO 9001 certified Leather-Footwear Chain organizations obtained certification because the organization was being pressured by their customers. Christmann and Taylor (2006) strengthen this idea by underlining that buyers rely on ISO certification as a screening device to identify potential suppliers, creating increased preference for certified suppliers.

Polo-Redondo and Cambra-Fierro (2008) posit that in the MSS context, this scenario can be understood as "reverse marketing". In reverse marketing, the buyer attempts to persuade the supplier to provide exactly what the buyer's organization needs (Leposky et al., 2017). In this sense, this scenario may lead to an increase in demand for MSS certifications throughout the supply chain because certified clients might require their suppliers to be certified; in turn, these suppliers might require the same from their immediate suppliers, which could lead to an unbroken chain of such demands all the way down the supply chain (Grosvold et al., 2014; Thorlakson et al., 2018). This notion of the chain of MSS certifications is endorsed by several authors (Christmann and Taylor, 2001; Cashore, 2002; Karapetrovic, 2003; Nishitani, 2009, 2010).

However, according to other researchers, when the number of certified organizations reaches a certain limit, certification becomes less attractive to other companies, as it loses its ability to differentiate firms, and a saturation of certification use occurs (Franceschini et al., 2004, 2006; Casadesús et al., 2008). In this context, Franceschini et al. (2010), Sampaio et al. (2011), and Franceschini et al. (2011) note that when organizations seem to have achieved a certain reputation and garnered a certain market share, the importance of certification tends to decline, and the number of new enterprises potentially interested in achieving certification decreases significantly within the supply chain.

For this reason, if firms located intermediately or further up the supply chain decrease their preference for MSS-certified suppliers, this adjusted preference can also reverberate throughout the entire chain because, as Kumar and Rahman (2015) and Thorlakson et al. (2018), standards move as they cascade throughout the supply chain, influencing both industrial buying behavior and the relationships that companies develop within the supply chain context.

Just as suppliers will likely have to meet customer needs to retain them in their customer portfolios (Polo-Redondo and Cambra-Fierro, 2008), non-certified suppliers that wish to enter certain supply chains may encounter difficulties in deciding which certification to adopt because they are unaware of their (potential) clients' preferences or even whether it is feasible to obtain any certification.

Prioritizing one or a few of the most important and desirable certifications in the desired supply chain can be important, particularly for small and medium-sized businesses, because of the high implementation costs of certifications (Santos et al., 2016). Thus, being aware of the MSS that companies prefer their suppliers to have is crucial both to generate competitive advantages for suppliers and to strengthen the chain within which they operate.

\section{RESEARCH METHOD}

\section{The Conjoint Analysis}

Conjoint analysis (CA) is a multivariate technique used to understand how respondents develop preferences for any type of object (including products, services or ideas). The CA technique provides the researcher with a substantial overview of the composition of respondent preferences while maintaining a high degree of realism (Hair et al., 2010), allowing for the study of complex situations in which several factors can influence an actor's final decision (Boesch, 2013).

In contrast to other multi-attribute models, CA is a decomposition technique for deriving part-worth estimates associated with the attributes of a choice alternative based on the statements of general preferences by a group of respondents (Reutterer and Kotzab, 2000).

The flexibility of CA means that it can be used in virtually any area in which there is a desire to study the intended decisions of a person or group of people (Hair et al. 2010). Thus, 
CA can be applied in several areas, including supply chain management (Reutterer and Kotzab, 2000; Naudé and Buttle, 2000; Wetzels et al., 1995).

The basic mathematical model of CA can be represented by the following general equation (Equation 1),

$$
U(X)=\sum_{i=1}^{m} \sum_{j=1}^{k_{i}} a_{i j} x_{i j}
$$

where $U(X)$ is the overall utility of an alternative, $a_{i j}$ is the part-worth utility associated with the $j$ th level of the ith attribute; $k_{\mathrm{i}}$ is the number of levels of attribute $i ; m$ is the number of attributes; and $x_{i j}=1$ if the $j$ th level of the $i$ th attribute is present and 0 otherwise.

The importance of an attribute $i$ is defined in terms of the range of part-worth through the level of that attribute. In addition, the importance of attribute $i$ relative to other attributes is determined by Equation 2 (Hollebeek et al., 2007; Malhotra 2012).

$$
R I_{i}=\frac{\max \left(a_{i j}\right)-\min \left(a_{i j}\right)}{\sum_{i=1}^{m} \max \left(a_{i j}\right)-\min \left(a_{i j}\right)}
$$

where $R I_{\mathrm{i}}$ is the relative importance of the ith attribute, and $\sum^{m} \cdot R I_{i}=1$. Thus, the RI can be interpreted as the weight that each attribute carries for someoneins decision, i.e., the weight of the attribute in the utility function.

Following the guidelines of the literature for the application of conjoint analysis (CA), in the current study, five attributes were aggregated and analyzed with an additive model. Therefore, a full profile approach was applied based on five attributes and two levels. It was considered that many stimuli might render the assessment task excessively tiring for the respondents, casting doubt on the quality of data collected (Hair et al., 2010). To reduce the number of stimuli, we employed a fractional factorial design, resulting in eight stimuli. The XLSTAT software (ADDINSOFT, 2016) was used to generate orthogonal arrays.

\section{Population and sample}

The research population consisted of approximately 201 Brazilian sugarcane companies registered with UNICA (The Brazilian Sugarcane Industry Association) and UDOP (The Brazilian Bioenergy Manufacturers Association).

A questionnaire was sent to middle or senior executives (general manager, logistics manager or quality manager) of 201 Brazilian sugarcane companies. Sixty-six questionnaires were answered correctly and formed the sample employed in this research, for a response rate of approximately 33\%. Thus, the sample was considered significant for the study (Forza, 2002; Voss et al., 2002).

In an industrial population, the response rate to survey requests is typically very low (Harzing, 1997, 2000; Fahy, 1998; Erdogan and Baker, 2002). Published empirical work by Corbett (2006), Psomas et al. (2010), Singh et al. (2011) and Psomas (2013), based on quality management surveys and published research by Reutterer and Kotzab (2000) and Naudé and Buttle (2000) utilizing industrial marketing surveys in connection with a CA, draw their conclusions from surveys with similar response rates.

According to Auty (1995), CA is particularly suited to industrial marketing research because the small sample size arising from a small population of buyers is not problematic. Thus, among surveys of industrial populations, our response rate is typical. In addition, the similarity of the economic and productive context of this sector is similar to that of other countries, allowing the study's approach and implications to be compared in other studies. 


\section{Conjoint design}

To validate the CA model, the attributes should be independent, and the levels of attributes must be mutually exclusive (Hair et al., 2010). In addition, the attributes should have the same number of levels (Wittink et al., 1990; Verlegh et al., 2002; Hair et al., 2010). To form the attributes, then, five of the most common MSS were selected that certify companies within the Brazilian sugarcane supply chain. Respondents were asked to express the degree of their preference when contracting with suppliers between those with or without MSS, i.e., to evaluate their preferences for certified and non-certified suppliers. In this manner, five attributes (ISO 9001, ISO 14001, ISO 22000, OHSAS 18001, and ISO 27001 and two levels (certified and non-certified companies) were employed, as shown in Table 1.

Table 1. Attributes and attribute levels

\begin{tabular}{cccccc}
\hline \multirow{2}{*}{ Attributes } & \multicolumn{5}{c}{ Management Systems Standards } \\
\cline { 2 - 6 } & ISO $\mathbf{9 0 0 1}$ & ISO 14001 & ISO 22000 & OHSAS 18001 & ISO 27000 \\
\hline Level 0 & Certified & Certified & Certified & Certified & Certified \\
\hline Level 1 & Non-certified & Non-certified & Non-certified & Non-certified & Non-certified \\
\hline
\end{tabular}

Source: The authors themselves

The number of stimuli generated with these attributes and their levels was $32\left(2^{5}\right)$. To reduce the number of stimuli and ensure the quality of responses (Hair et al., 2010), a fractional factorial design was developed. This process resulted in eight stimuli, making the research instrumentally manageable for respondents. Table 2 presents the combinations of stimuli generated.

\section{Data collection and data analysis}

The questionnaire, which was divided into two parts with instructions, was distributed to the initial 201 companies via e-mail. The first part consisted of questions regarding certain company characteristics, and the second part consisted of questions from the CA. Respondents were asked to evaluate each of the eight stimuli using a structured 9-box grid labeled from the left with "1 = unimportant" to "9 = very important" (Malhotra, 2012). The preference measuring method by assessment scale was chosen for ease of application because the questionnaires were sent by e-mail (Hair et al., 2010).

The dataset was analyzed using the Conjoint Design package in the XLSTAT software (ADDINSOFT, 2016) to estimate relative importance through the utility value of each attribute. Significant differences in part-worth and relative importance were calculated using the Kruskal-Wallis test at $a=0.05$.

Table 2. Description of the stimuli presented to participants and corresponding attribute levels

\begin{tabular}{cccccc}
\hline $\begin{array}{c}\text { Number of } \\
\text { Stimuli }\end{array}$ & \multicolumn{5}{c}{ Management Systems Standards } \\
\cline { 2 - 5 } 1 & ISO $\mathbf{9 0 0 1}$ & ISO 14001 & ISO 22000 & OHSAS 18001 & ISO 27000 \\
Non-certified & Non-certified & Certified & Certified & Non-certified \\
\hline 2 & Certified & Non-certified & Non-certified & Certified & Non-certified \\
\hline 3 & Certified & Certified & Certified & Certified & Certified \\
\hline 4 & Certified & Certified & Non-certified & Non-certified & Non-certified \\
5 & Certified & Non-certified & Certified & Non-certified & Certified \\
6 & Non-certified & Certified & Non-certified & Certified & Certified \\
\hline 7 & Non-certified & Non-certified & Non-certified & Non-certified & Certified \\
\hline 8 & Non-certified & Certified & Certified & Non-certified & Non-certified \\
\hline
\end{tabular}

Source: The authors themselves 


\section{RESULTS}

Of the 66 respondent companies, 61 (92\%) were large and 21 (32\%) exported to other countries. Of these, 22 (33\%) were ISO 9001-certified companies, 12 (18\%) were ISO 22000certified companies, 6 (9\%) were ISO 14001-certified companies, and only 2 (3\%) were OHSAS 18001-certified companies. No company was ISO 27001-certified. Of these 66 companies, 14 (21\%) were non-certified, and the remainder were certified with at least one MSS. Additional company characteristics are presented in Table 3.

Table 3. Characteristics of the companies studied

\begin{tabular}{cc}
\hline Characteristics & $\%$ \\
\hline Certified companies & 33 \\
\hline MSS ISO 9001 & 9 \\
\hline MSS ISO 14001 & 18 \\
\hline MSS ISO 22000 & 3 \\
\hline MSS OHSAS 18001 & 0 \\
\hline MSS ISO 27001 & 92 \\
\hline Size & 8 \\
\hline Large (500 employees or more) & 30 \\
\hline Medium (< 500 employees) & 50 \\
\hline Operating time & 20 \\
\hline$<10$ years & 32 \\
\hline 10 to 19 years & 68 \\
\hline$>20$ years & 30 \\
\hline Export companies & \\
\hline Yes & \\
\hline No & \\
\hline
\end{tabular}

The part-worth utility (PWU) and relative importance (RI) values are presented in Table 4. Significant differences were calculated using the Kruskal-Wallis test at $a=0.05$. Source: The authors themselves

Table 4. Part-worth utilities and relative attribute importance

\begin{tabular}{ccccc}
\hline Attributes & Levels & PWU & RI & SD \\
\hline MSS ISO 9001 & Certified & $1.538^{\mathrm{b}}$ & $38.7 \%^{\mathrm{c}}$ & 9.86 \\
\hline & Non-certified & $-1.538^{\mathrm{a}}$ & & \\
\hline MSS ISO 14001 & Certified & $0.769^{\mathrm{b}}$ & $19.6 \%^{b}$ & 7.26 \\
\hline \multirow{2}{*}{ MSS ISO 22000 } & Non-certified & $-0.769^{\mathrm{a}}$ & & \\
\hline \multirow{2}{*}{ MSS OHSAS 18001 } & Certified & $0.545^{\mathrm{b}}$ & $19.9 \%^{b}$ & 7.75 \\
\hline \multirow{2}{*}{ MSS ISO 27001 } & Non-certified & $-0.545^{\mathrm{a}}$ & & 7.32 \\
\hline & Certified & $0.208^{\mathrm{b}}$ & $13.2 \%^{a}$ & \\
\hline Constant value & Non-certified & $-0.208^{\mathrm{a}}$ & & \\
\hline
\end{tabular}

Part-worth utilities for the same attribute and relative importance with different letters within the same column are significantly different $(p \leq 0.05)$, according to the Kruskal-Wallis multiple comparisons test. Negative symbols signify a negative impact on consumer preference. Source: The authors themselves

Table 4 shows that the most important attribute presented by the participating companies was the ISO 9001 (RI = 38.7\%). ISO 22000 and ISO 14001 certifications presented statistically similar levels of relative importance, at $19.9 \%$ and $19.6 \%$, respectively. The OHSAS 18001 and ISO 27001 also presented statistically similar levels of $\mathrm{RI}$, at $13.2 \%$ and $8.6 \%$, respectively. This statistical evidence suggested a hierarchy of preference among the standards analyzed: $38.7 \%$ for ISO $9001,19.9 \%$ for ISO $22000,19.6 \%$ for ISO $14001,13.2 \%$ for OHSAS 18001 and 8.6\% for 27001. 
The company responses indicated that Brazilian sugarcane companies were significantly influenced by ISO 9001-certified suppliers, followed by ISO 22000- and ISO 14001-certified suppliers, and then by OHSAS 18001- and ISO 27001-certified suppliers, according to the Kruskal-Wallis test $(\mathrm{p} \leq 0.05)$.

Table 4 also shows that the companies studied demonstrated a significant preference for MSS-certified suppliers irrespective of importance level, as shown by the positive signs of the corresponding PWU values, according to the Kruskal-Wallis test $(p \leq 0.05)$. This result establishes that there is a positive preference for MSS-certified suppliers.

Thus, this result might indicate that the certification of productive processes is perceived as a sign of quality that helps increase the company's credibility and reputation in the eyes of its customers, as verified by numerous authors (Stevenson and Barnes, 2002; Chatterjee et al., 2005; Aldowaisan and Youssef, 2006; Polo-Redondo and Cambra-Fierro, 2008; Hoejmose et al., 2014). Moreover, it might also indicate that companies feel assured that certified suppliers may bring benefits to a long-term relationship with the organization, as indicated by Polo-Redondo and Cambra-Fierro (2008).

With respect to the relationship between preferences and increases/decreases in the number of certificates issued in Brazil, these characteristics demonstrably conflict with the information contained in the conceptual framework of this study.

Franceschini et al. $(2010,2011)$ and Sampaio et al. (2011) indicate that when the number of certified organizations reaches a certain limit, certification begins to become less attractive for companies, and it is expected that a reduction in the preference for ISO 9001 and 14001 certifications in Brazil will occur because the number of these certifications has decreased in recent years.

However, ISO 9001-certified suppliers generated a higher preference among the surveyed companies, and ISO 14001-certified suppliers showed an intermediate level of importance. Therefore, in this study, no evidence was observed in the data to establish that there is less preference for suppliers certified by ISO 9001 or by ISO 14001.

Nevertheless, Brazil's industrial sector has also shown an increase in the number of ISO 27001 and OHSAS 18001 certifications in recent years (International Organization for Standardization, 2013). In this context, the research shows no evidence for the perception of a stronger preference for ISO 27001-certified suppliers or a stronger preference for OHSAS 18001. Although the number of ISO 22000 certifications has increased recently, and certification has obtained a relatively intermediate level of importance-at least as important as the ISO 14001 certification-no evidence was found to establish that companies within the supply chain studied have a higher preference for suppliers certified by ISO 22000.

In this context, the results indicate that MSS-certified companies do not lose their ability to differentiate themselves when certification becomes common. Indeed, ISO 9001-certified suppliers remained the most preferred. In this way, while this scenario shows a saturation that is similar to that noted and described by Franceschini et al. $(2004,2006,2010,2011)$ and Sampaio et al. (2011), no reductions were observed in the degree of client preference for MSScertified suppliers.

It seems that, as saturation does not influence client preferences regarding certified suppliers, other factors must be studied. For example, recertification is required periodically, i.e., companies maintain their valid certification for a certain period, during which there are few new companies to certify, which may explain why the numbers of ISO 9001 and ISO 14001 certifications have decreased even when the preference for these certifications has not lessened. Thus, the saturation reduced with no concurrent reduced preference for certified suppliers.

Specifically, with respect to ISO 14001, Bowen (2002), González-Benito and GonzálezBenito (2006), Hoejmose et al. (2012) and Boiral et al. (2017) indicate that firms located further down the chain - and therefore not immediately visible to end consumers-might be relatively reactive in terms of their "green" environmental efforts, and it may be that firms in B2B markets lack the appropriate knowledge or interest to systematically implement these processes. 
The intermediate preference for ISO 14001-certified suppliers might result from the fact that not all sugarcane companies are immediately visible to end consumers. Although ISO 22000 is statistically similar to the preference for ISO 14001, ISO 22000 certified suppliers enjoy slightly higher preference.

Based on these results, the statistical evidence suggests and corroborates the perception that ISO 9001 is a certification that can be considered a mandatory factor, whereas the others can be considered as qualifiers and, therefore, after preference for the standard that addresses the standardization of products and processes (ISO 9001), the industry places a preference on the standard that addresses the requirements of food safety throughout the production chain (ISO 22000).

Preference was observed to be associated with standards that guide practices and environmental issues (ISO 14001), followed by the standard that includes the minimum requirements for occupational health and safety management (OHSAS 18001) and, lastly, a preference for the standard that deals with information security (ISO 27001). Thus, the answer to the first research problem reveals the following preference order: ISO 9001, ISO 22000, ISO 14001, OHSAS 18001 and ISO 27001.

Indeed, it might be natural to expect a higher degree of preference for food companies certified with this standard in this sector. In any event, further research should be conducted to study the behavior of industrial buying and factors that can influence companies' preference for certification and certified companies within the supply chain.

\section{Practical/managerial implications}

Demand remains for ISO 9001 certification in the Brazilian sugarcane sector, which might indicate that opportunities remain for suppliers to gain a competitive advantage in this supply chain if they obtain or maintain these certifications and (consequently) to strengthen the chain within which they operate and maintain (or improve) the relations between suppliers and customers in supply management, as noted in the literature and previously described in this paper.

In any case, this result is important because suppliers are more likely to choose substantive certification when customers place high importance on the standard, as reported by Christmann and Taylor (2006). For many companies, certifications are substantial difference makers in the market that provide competitive advantages and enable entry into new markets or new supply chains (Dimara et al., 2004; Christmann and Taylor, 2006; Fraj et al., 2013).

However, companies that adopt MSS certifications only to insert themselves into new markets, i.e., purely for external reasons, have been criticized in the literature (Jones et al., 1997; Boiral and Roy, 2007; Dick et al., 2008; Polo-Redondo and Cambra-Fierro, 2008; Sroufe and Curkovic, 2008; Prajogo, 2011; Singh et al., 2011).

Nevertheless, Dimara et al. (2004) argue that if market differentiation is an objective or an organizational strategy, it is possible to acquire advantages, such as a statistically significant growth in turnover and market share, that would justify obtaining certification. Furthermore, Christmann and Taylor (2006) suggest that if the symbolic implementation is sufficient to satisfy customers, then firms will choose symbolic implementation.

In this context, our findings demonstrate to practitioners/managers that even if they do so for external reasons, suppliers wishing to participate in this supply chain should obtain ISO 9001, ISO 14001 and ISO 22000 certifications, if feasible. Moreover, this research opens space in the industrial marketing literature to promote (and explore) research on the certification of corporate earnings because this research points to evidence that even in a market that appears to be saturated with particular certifications, client companies still have strong preferences for suppliers with these traditional certifications.

\section{CONCLUSIONS}

The data, analyses and statistical evidence presented in this research allowed the verification of the existence of a preference among contracting companies (clients) that companies that provide services to customers in the supply chain have MSS certificates. 
According to statistical tests $(p<0.05)$, companies adopt different preference levels for suppliers with different certifications. It has also been shown that the presence of any MSS was valued by respondents.

The results of the CA revealed that participants prefer ISO 9001-certified suppliers, followed by ISO 22000-, ISO 14001-, OHSAS 18001-, and, finally, ISO 27001-certified suppliers. These results therefore establish the order of preference among the MSS analyzed in this paper, responding to the first and second research problems.

In addition, the data did not clearly show that the saturation of the number of certified companies influences the preferences between the two actors in this research (client and certified suppliers). Thus, the preference for certified suppliers is not influenced when a certain threshold (in the number of certifications) is reached. These observations, therefore, respond to the third research problem.

Thus, this work makes several contributions to the literature on the management of organizations involved in the supply chains observed in agribusiness. First, it was empirically verified that in Brazil, the fact that the supplier is certified was viewed positively by companies in this sector. Second, even as the number and rate of ISO 9001 and ISO 14001 certifications are decreasing in Brazil, the sugarcane sector still valued suppliers with these certifications, particularly ISO 9001, which continued to garner the highest relative importance. Therefore, in the current scenario, these certifications, including ISO 22000, still generate competitive advantages both for certified suppliers and for companies that intend to obtain registration.

In this context, the results show that MSS-certified companies do not lose their ability to differentiate themselves when certifications become common. Although the number of adopters of some certifications is increasing, companies within the supply chain still prefer the traditional certifications, even when the market is saturated with such certifications.

These results help better explain industrial behavior and illuminate the relationships that companies develop within the supply chain, that might thus be of great assistance to suppliers wishing to become part of this supply chain by identifying which MSS certifications are most valued by purchasing companies, which is the primary practical/managerial implication of this study. These findings are important because, according to Christmann and Taylor (2006), the importance placed by a client on the specific MSS may influence the choice or prioritization of MSS under the perspective of the partner service provider.

In addition, we are unaware of any previous study in the marketing, MSS certifications, and agribusiness management literature showing that companies in a supply chain prefer suppliers with any of the main MSS available on the market.

\section{Limitations and further research}

It is considered that this study is the first step toward measuring the preference structure of companies for certified suppliers. Future studies with goals similar to those of the present study should be conducted in other Brazilian sectors or in other countries. Other MSS might also be involved and evaluated based on the sector under study. Moreover, based on the observed preferences, such research could establish and test hypotheses.

A greater number of company observations might also improve both this study's results and other variables for classifying companies, which might provide better conditions with which to define different company profiles and assess the differences in their preference structures. These characteristics would alleviate some limitations of this study.

\section{REFERENCES}

ADDINSOFT. (2016), XLSTAT. Statistical software core, ADDINSOFT, Paris.

Aldowaisan, T.A. and Youssef, A.S. (2006), "An ISO 9001:2000-based framework for realizing quality in small businesses", Omega, Vol. 34, No. 3, pp. 231-5.

Almeida, M.H., Caten, C.S.T. and Gutterres, M. (2009), "Evaluating ISO 9001:2000 certified and noncertified organizations in brazilian leather-footwear chain", Brazilian Journal of Operations \& Production Management, Vol. 6, No. 2, pp. 51-73. 
Auty, S. (1995), "Using conjoint analysis in industrial marketing: the role of judgment", Industrial Marketing Management, Vol. 24, No. 3, pp. 191-206.

Behzadi, G., O'Sullivan, M.J., Olsen, T.L. et al. (2017), "Agribusiness supply chain risk management: a review of quantitative decision models", Omega, Vol. 74, pp. 21-42.

Boesch, I. (2013), "Preferences of processing companies for attributes of Swiss milk: a conjoint analysis in a business-to-business market", Journal of Dairy Science, Vol. 96, No. 4, pp. 2183-9.

Boiral, O. (2003), "ISO 9000: outside the iron cage", Organization Science, Vol. 14, No. 6, pp. 720-37.

Boiral, O. and Roy, M.J. (2007), "ISO 9000: integration rationales and organizational impacts", International Journal of Operations \& Production Management, Vol. 27, No. 2, pp. 226-47.

Boiral, O., Guillaumie, L., Heras-Saizarbitoria, I. et al. (2017), "Adoption and outcomes of ISO 14001: a systematic review", International Journal of Management Reviews, No. 1, pp. 1-22. In press.

Bornia, A.C., Gisi, M.F.S., Spenassato, D. et al. (2016), "An exploratory survey on the topic integrated management systems", Brazilian Journal of Operations \& Production Management, Vol. 13, pp. 184-93.

Bowen, F.E. (2002), "Does size matter", Business \& Society, Vol. 41, No. 1, pp. 118-24.

Casadesús, M., Marimon, F. and Heras, I. (2008), "ISO 14001 Diffusion after the success of the ISO 9001 model", Journal of Cleaner Production, Vol. 16, No. 16, pp. 1741-54.

Cashore, B. (2002), "Legitimacy and the privatization of environmental governance: how non-state market-driven (NSMD) governance systems gain rule-making authority", Governance: An International Journal of Policy, Administration and Institutions, Vol. 15, No. 4, pp. 503-29.

Chatterjee, S., Kang, Y.S. and Mishra, D.P. (2005), "Market signals and relative preference: The moderating effects of conflicting information, decision focus, and need for cognition",Journal of Business Research, Vol. 58, No. 10, pp. 1362-70.

Christmann, P. \& Taylor, G. (2001). "Globalization and the environment: determinants of firm self-regulation in China", Journal of International Business Studies, Vol. 32 No. 3, pp. 438-458.

Christmann, P. and Taylor, G. (2002), "Globalization and the environment: Strategies for international voluntary environmental initiatives", The Academy of Management Executive, Vol. 16, No. 3, pp. 121-35.

Christmann, P. and Taylor, G. (2006) "Firm self-regulation through international certifiable standards: Determinants of symbolic versus substantive implementation". Journal of International Business Studies, Vol. 37, No. 6, pp. 863-78.

Corbett, C.J. (2006), "Global diffusion of ISO 9000 certification through supply chains", Manufacturing \& Service Operations Management: M \& SOM, Vol. 8, No. 4, pp. 330-50.

Corbett, C.J. and Kirsch, D.A. (2001), "International diffusion of ISO 14000 certification", Production and Operations Management, Vol. 10, No. 3, pp. 327-42.

Czinkota, M.; Kaufmann, H. R.; Basile, G. (2014). "The relationship between legitimacy, reputation, sustainability and branding for companies and their supply chains", Industrial Marketing Management, Vol. 43, pp. 91-101.

del Mar Alonso-Almeida, M., Marimon, F. and Bernardo, M. (2013), "Diffusion of quality standards in the hospitality sector", International Journal of Operations \& Production Management, Vol. 33, No. 5, pp. 504-27.

Desai, V.M. (2018), "Third-party certifications as an organizational performance liability", Journal of Management, Vol. 44, No. 8, pp. 3096-123.

Dick, G.P.M., Heras, I. and Casadesús, M. (2008), "Shedding light on causation between ISO 9001 and improved business performance", International Journal of Operations \& Production Management, Vol. 28, No. 7, pp. 687-708.

Dimara, E., Skuras, D., Tsekouras, K. et al. (2004), "Strategic orientation and financial performance of firms implementing ISO 9000", International Journal of Quality \& Reliability Management, Vol. 21, No. 7, pp. 72-89.

Erdogan, B.Z. and Baker, M. J. (2002) "Increasing mail survey response rates from an industrial population". Industrial Marketing Management, Vol. 31, No. 1, pp. 65-73.

Fahy, J. (1998), "Improving response rates in cross-cultural mail surveys", Industrial Marketing Management, Vol. 27, No. 6, pp. 459-67.

Fava Neves, M., Fava Scare, R. and Goldsmith, P.D. (2010), "Defining an agribusiness strategic agenda for 2010-2020", The International Food and Agribusiness Management Review, Vol. 13, No. 1, pp. 83-90. 
Ferguson, W. (1996), "Impact of the ISO 9000 series standards on industrial marketing", Industrial Marketing Management, Vol. 25, No. 4, pp. 305-10.

Forza, C. (2002), "Survey research in operations management: a process-based perspective", International Journal of Operations \& Production Management, Vol. 22, No. 2, pp. 152-94.

Fraj, E., Martínez, E. and Matute, J. (2013), "Green marketing in B2B organizations: an empirical analysis from the natural-resource-based view of the firm", Journal of Business and Industrial Marketing, Vol. 28, No. 5, pp. 396-410.

Franceschini, F., Galetto, M. and Cecconi, P. (2006), "A worldwide analysis of ISO 9000 standard diffusion", Benchmarking, Vol. 13, No. 4, pp. 523-41.

Franceschini, F., Galetto, M. and Giannì, G. (2004), "A new forecasting model for the diffusion of ISO 9000 standard certifications in European countries", International Journal of Quality \& Reliability Management, Vol. 21, No. 1, pp. 32-50.

Franceschini, F., Galetto, M., Maisano, D. et al. (2010), "Clustering of European countries based on ISO 9000 certification diffusion", International Journal of Quality \& Reliability Management, Vol. 27, No. 5, pp. 558-75.

Franceschini, F., Galetto, M., Maisano, D. et al. (2011), "A proposal of a new paradigm for national quality certification systems", International Journal of Quality \& Reliability Management, Vol. 28, No. 4, pp. 36482.

Freitas, L.C. and Kaneko, S. (2011), "Ethanol demand in Brazil: regional approach", Energy Policy, Vol. 39, No. 5, pp. 2289-98.

Ge, H., Gray, R. and Nolan, J. (2015), "Agricultural supply chain optimization and complexity: A comparison of analytic vs simulated solutions and policies", International Journal of Production Economics, Vol. 159, pp. 208-20.

Gilio, L. and Moraes, M.A.F.D. (2016), "Sugarcane industry's socioeconomic impact in São Paulo, Brazil: A spatial dynamic panel approach", Energy Economics, Vol. 58, No. 1, pp. 27-37.

González-Benito, J. and González-Benito, Ó. (2006), "A review of determinant factors of environmental proactivity", Business Strategy and the Environment, Vol. 15, No. 2, pp. 87-102.

Gray, J.V., Anand, G. and Roth, A.V. (2015), "The influence of ISO 9000 certification on process compliance", Production and Operations Management, Vol. 24, No. 3, pp. 369-82.

Grosvold, J., Hoejmose, S.U., \& Roehrich, J. (2014), "Squaring the circle: management, measurement and performance of sustainability in supply chains", Supply Chain Management, Vol. 19, No. 3, pp. 292-305.

Hair, J., Black, W.C., Babin, B.J. et al. (2010), Multivariate Data Analysis, Prentice Hall, Upper Saddle River, NJ.

Harzing, A.W. (1997), "Response rates in international mail surveys: results of a 22-country study", International Business Review, Vol. 6, No. 6, pp. 641-65.

Harzing, A.W. (2000), "Cross-national industrial mail surveys", Industrial Marketing Management, Vol. 29, No. 3, pp. 243-54.

Heras-Saizarbitoria, I. and Boiral, O. (2013), "ISO 9001 and ISO 14001: towards a research agenda on management system standards", International Journal of Management Reviews, Vol. 15, No. 1, pp. 4765.

Hira, A. and Oliveira, L.G. (2009), "No substitute for oil? How Brazil developed its ethanol industry", Energy Policy, Vol. 37, No. 6, pp. 2450-6.

Hoejmose, S., Brammer, S. and Millington, A. (2012), "'Green” supply chain management: the role of trust and top management in B2B and B2C markets", Industrial Marketing Management, Vol. 41, No. 4, pp. 609-20.

Hoejmose, S.U., Roehrich, J.K. and Grosvold, J. (2014), "Is doing more doing better? The relationship between responsible supply chain management and corporate reputation", Industrial Marketing Management, Vol. 43, No. 4, pp. 77-90.

Hollebeek, L.D., Jaeger, S.R., Brodie, R.J. et al. (2007), "The influence of involvement on purchase intention for new world wine", Food Quality and Preference, Vol. 18, No. 8, pp. 1033-49.

Jones, R., Arndt, G. and Kustin, R. (1997), "ISO 9000 among Australian companies: impact of time and reasons for seeking certification on perceptions of benefits received", International Journal of Quality \& Reliability Management, Vol. 14, No. 7, pp. 650-60.

Karapetrovic, S. (2003), "Musings on integrated management systems", Measuring Business Excellence, Vol. 7, No. 1, pp. 4-13. 
Karapetrovic, S. and Willborn, W. (1998a), "Integration of quality and environmental management systems", The TQM Magazine, Vol. 10, No. 3, pp. 204-13.

Karapetrovic, S. and Willborn, W. (1998b), "The system's view for clarification of quality vocabulary", International Journal of Quality \& Reliability Management, Vol. 15, No. 1, pp. 99-120.

Khan, A. and Farooquie, J.A. (2016), "Motives and benefits of ISO 9001 quality management system: an empirical study of Indian SMES", Brazilian Journal of Operations \& Production Management, Vol. 13, pp. 320-9.

Kumar, D., \& Rahman, Z. (2015). "Sustainability adoption through buyer supplier relationship across supply chain: a literature review and conceptual framework". International strategic management review, Vol, 3, No. 1, pp. 110-127.

Leposky, T., Arslan, A. and Kontkanen, M. (2017), "Determinants of reverse marketing knowledge transfer potential from emerging market subsidiaries to multinational enterprises' headquarters", Journal of Strategic Marketing, Vol. 25, No. 7, pp. 567-80.

Licht, F.O. (2007). "In renewable fuels association-industry statistics 2008", available at: http://www.ethanolrfa.org/industry/statistics (accessed 11 February 2018).

Liu, H., Wu, S., Zhong, C. et al. (2020), "An empirical exploration of quality management practices and firm performance from Chinese manufacturing industry", Total Quality Management \& Business Excellence, pp. 1-19.

Lizarraga, M.S., Romero, J.L., Mendoza, D.A.T. et al. (2020), "'ISO 9001 standard: exploratory analysis in the manufacturing sector in Mexico". DYNA: revista de la Facultad de Minas, Vol. 87, No. 213, pp. 202-11.

Malhotra, N.K. (2012), Marketing research: an applied orientation. Porto Alegre: Bookman.

Miles, M.P., Munilla, L.S. and Russell, G.R. (1997), "Marketing and environmental registration/certification: what industrial marketers should understand about ISO 14000", Industrial Marketing Management, Vol. 26, No. 4, pp. 363-70.

Naudé, P. and Buttle, F. (2000), "Assessing relationship quality", Industrial Marketing Management, Vol. 29, No. 4, pp. 351-61.

Nishitani, K. (2009), "An empirical study of the initial adoption of ISO 14001 in Japanese manufacturing firms", Ecological Economics, Vol. 68, No. 3, pp. 669-79.

Nishitani, K. (2010), "Demand for ISO 14001 adoption in the global supply chain: an empirical analysis focusing on environmentally conscious markets", Resource and Energy Economics, Vol. 32, No. 3, pp. 395-407.

Özdemir, A.İ., Simonetti, B. and Jannelli, R. (2015), "Determining critical success factors related to the effect of supply chain integration and competition capabilities on business performance", Quality \& Quantity, Vol. 49, No. 4, pp. 1621-32.

Pagani, V., Stella, T., Guarneri, T. et al. (2017), "Forecasting sugarcane yields using agro-climatic indicators and Canegro model: a case study in the main production region in Brazil", Agricultural Systems, Vol. 154, No. 1, pp. 45-52.

Polo-Redondo, Y. and Cambra-Fierro, J. (2008), "Influence of the standardization of a firm's productive process on the long-term orientation of its supply relationships: an empirical study", Industrial Marketing Management, Vol. 37, No. 4, pp. 407-20.

Prajogo, D.I. (2011), "The roles of firms' motives in affecting the outcomes of ISO 9000 adoption", International Journal of Operations \& Production Management, Vol. 31, No. 1, pp. 78-100.

Proches, C.G. and Bodhanya, S. (2015), "Exploring stakeholder interactions through the lens of complexity theory: lessons from the sugar industry", Quality \& Quantity, Vol. 49, No. 6, pp. 2507-25.

Psomas, E.L. (2013), "The effectiveness of the ISO 9001 quality management system in service companies", Total Quality Management \& Business Excellence, Vol. 24, No. 7-8, pp. 769-81.

Psomas, E.L., Fotopoulos, C.V. and Kafetzopoulos, D.P. (2010), "Critical factors for effective implementation of ISO 9001 in SME service companies", Managing Service Quality, Vol. 20, No. 5, pp. 440-50.

Ramos, A.R., Ferreira, J.C.E., Kumar, V. et al. (2018), "A lean and cleaner production benchmarking method for sustainability assessment: a study of manufacturing companies in Brazil", Journal of Cleaner Production, Vol. 177, pp. 218-31.

Renewable Fuels Association - RFA. (2014), World fuel ethanol production, RFA, Washington.

Reutterer, T. and Kotzab, H.W. (2000), "The use of conjoint-analysis for measuring preferences in supply chain design", Industrial Marketing Management, Vol. 29, No. 1, pp. 27-35. 
Rosa, A.A.S., Abdala, E.C. and Cezarino, L.O. (2019), "Sustainable practices and the relationship with suppliers in SSCM: a case study in wholesale", Brazilian Journal of Operations \& Production Management, Vol. 16, pp. 413-23.

Sampaio, P., Saraiva, P. and Domingues, P. (2012), "Management systems: Integration or addition", International Journal of Quality \& Reliability Management, Vol. 29, No. 4, pp. 402-24.

Sampaio, P., Saraiva, P. and Guimarães Rodrigues, A.G. (2011), "ISO 9001 certification forecasting models", International Journal of Quality \& Reliability Management, Vol. 28, No. 1, pp. 5-26.

Santos, G., Rebelo, M., Lopes, N. et al. (2016), "Implementing and certifying ISO 14001 in Portugal: motives, difficulties and benefits after ISO 9001 certification", Total Quality Management \& Business Excellence, Vol. 27, No. 11-12, pp. 1211-23.

Sharma, N.; Young, C. L.; Wilkinson, I. (2015),"The nature and role of different types of commitment in interfirm relationship cooperation", Journal of Business \& Industrial Marketing, Vol. 30, No. 1, pp. 45 - 59.

Singh, P.J., Power, D. and Chuong, S.C. (2011), "A resource dependence theory perspective of ISO 9000 in managing organizational environment", Journal of Operations Management, Vol. 29, No. 1-2, pp. 4964.

Sroufe, R. and Curkovic, S. (2008), "An examination of ISO 9000:2000 and supply chain quality assurance", Journal of Operations Management, Vol. 26, No. 4, pp. 503-20.

Stevenson, T.H. and Barnes, F.C. (2002), "What industrial marketers need to know now about ISO 9000 certification: a review, update, and integration with marketing", Industrial Marketing Management, Vol. 31, No. 8, pp. 695-703.

Su, H.C., Kao, T.W.D. and Linderman, K. (2020), "Where in the supply chain network does ISO 9001 improve firm productivity?", European Journal of Operational Research, Vol. 283, No. 2, pp. 530-40.

Thorlakson, T., Hainmueller, J. and Lambin, E.F. (2018), "Improving environmental practices in agricultural supply chains: the role of company-led standards", Global Environmental Change, Vol. 48, pp. 32-42.

Vachon, S. and Klassen, R.D. (2002), "An exploratory investigation of the effects of supply chain complexity on delivery performance", IEEE Transactions on Engineering Management, Vol. 49, No. 3, pp. 218-30.

Vafaei, S., Bazrkar, A. and Hajimohammadi, M. (2019), "The investigation of the relationship between sustainable supply chain management and sustainable competitive advantage according to the mediating role of innovation and sustainable process management", Brazilian Journal of Operations \& Production Management, Vol. 16, No. 4, pp. 572-80.

Verlegh, P.W.J., Schifferstein, H.N.J. and Wittink, D.R. (2002), "Range and number-of-levels effects in derived and stated measures of attribute importance", Marketing Letters, Vol. 13, No. 1, pp. 41-52.

Voss, C., Tsikriktsis, N. and Frohlich, M. (2002), "Case research in operations management", International Journal of Operations \& Production Management, Vol. 22, No. 2, pp. 195-219.

Wetzels, M., de Ruyter, K., Lemmink, J. et al. (1995), "Measuring customer service quality in international marketing channels: a multimethod approach", Journal of Business and Industrial Marketing, Vol. 10, No. 5, pp. 50-9.

Wittink, D.R., Krishnamurthi, L. and Reibstein, D.J. (1990), "The effect of differences in the number of attribute levels on conjoint results", Marketing Letters, Vol. 1, No. 2, pp. 113-23.

Author contributions: All the authors contributed equally to this paper. 